\title{
GAMBARAN PENGETAHUAN IBU HAMIL TENTANG PREVENTION \\ OF MOTHER TO CHILD HIV TRANSMISSION ( PMTCT) \\ DI DESA BANDUNG KECAMATAN PRAMBON KABUPATEN NGANJUK
}

Lely Khulafa'ur R ${ }^{1}$,Rizkiana Fitri ${ }^{2}$

Akademi Kebidanan Dharma Husada Kediri

\begin{abstract}
ABSTRAK
PMTCT yaitu upaya untuk mencegah infeksi HIV pada perempuan, serta mencegah penularan HIV dari ibu hamil ke bayi. Program PMTCT sekarang memberikan layanan dalam 4 pilar. Implementasi yang dapat dilakukan oleh perawat maternitas adalah sesuai dengan 4 peran yakni memberikan pelayanan secara langsung, konseling, promosi kesehatan dan penelitian. Penelitian ini bertujuan untuk mengetahui gambaran tingkat pengetahuan ibu hamil tentang PMTCT.

Desain penelitian ini menggunakan desain deskriptif, peneliti melakukan penelitian pada tanggal 11 Mei 2014 di Desa Bandung Kecamatan Prambon Kabupaten Nganjuk. Populasi dari penelitian ini adalah semua ibu hamil di Desa Bandung Kecamatan Prambon Kabupaten Nganjuk. Populasi berjumlah 42 orang. Teknik sampling yang digunakan adalah purposive sampling dan melakukan pendekatan cross sectional sehingga diperoleh 30 respoden. Variabel penelitian ini adalah variabel tunggal yaitu gambaran pengetahuan ibu hamil tentang PMTCT . Pengambilan data menggunakan kuesioner diolah dengan editing, coding, scoring, tabulating, dan hasilnya dianalisis dengan prosentase.

Dari hasil penelitian menunjukkan bahwa sebagian besar pengetahuan ibu hamil tentang PMTCT yaitu sebanyak 17 responden $(56,66 \%)$ berpengetahuan cukup, 6 responden ( $20 \%$ ) berpengetahuan kurang.

Hasil analisis menggunakan Distribusi Normal telah didapatkan bahwa penelitian ini terdistribusi normal.

Berdasarkan hasil penelitian dapat diketahui bahwa pengetahuan ibu hamil temtang PMTCT cukup. Setelah penelitian ini diharapkan pada ibu hamil agar lebih aktif dalam mencari informasi untuk menambah wawasan. Begitu juga dengan tenaga kesehatan hendaknya memberikan penyuluhan yang lebih terhadap ibu hamil agar lebih mengerti tentang PMTCT.
\end{abstract}

Kata Kunci : Pengetahuan, ibu hamil, PMTCT

59 | Jurnal Kebidanan Dharma Husada Vol. 4, No. 2 Oktober 2015 


\section{PENDAHULUAN}

Di Indonesia, infeksi HIV (Human Immunodeficiency Virus) merupakan salah satu penyakit menular yang dikelompokkan sebagai faktor yang dapat mempengaruhi kematian ibu dan anak. Meskipun berbagai upaya telah dilaksanakan selama beberapa tahun, masih perlu upaya peningkatan cakupan pelaksanaan program PMTCT (Prevention of mother to Child HIV Transmission) yang terintegrasi di layanan KIA (Kesehatan Ibu dan Anak) sejalan dengan perkiraan peningkatan beban. (Kemenkes, 2013:14).

Program PMTCT adalah program untuk mencegah transmisi infeksi HIV dari ibu ke bayi. Untuk mengatasi transmisi infeksi dari ibu ke bayi/anak, sejak tahun 2007 pemerintah telah mengeluarkan program PMTCT. Program PMTCT sekarang memberikan layanan dalam 4 pilar. Implementasi yang dapat dilakukan oleh perawat maternitas adalah sesuai dengan 4 peran yakni memberikan pelayanan secara langsung, konseling, promosi kesehatan dan penelitian. (Depkes RI, 2008:38).

Layanan PMTCT dalam pelayanan KIA merupakan bagian dari Program Nasional Pengendalian HIV/AIDS dan IMS (Infeksi Menular Seksual), di daerah epidemi HIV meluas dan terkonsentrasi, tenaga kesehatan di fasilitas pelayanan kesehatan wajib menawarkan tes HIV kepada semua ibu hamil secara inklusif pada pemeriksaan laboratorium rutin lainnya saat pemeriksaan antenatal atau menjelang persalinan, di daerah epidemi HIV rendah, penawaran tes HIV oleh tenaga kesehatan diprioritaskan pada ibu hamil dengan IMS dan TB (Tuberkulosis). Setiap ibu hamil yang positif HIV wajib diberi obat ARV (Antiretrioviral) dan mendapatkan pelayanan perawatan, dukungan dan pengobatan lebih lanjut. (Kemenkes, 2013).

Di banyak negara berkembang, HIV merupakan penyebab utama kematian perempuan usia reproduksi. Pada tahun 2010 diperkirakan terdapat $57.000 \mathrm{ibu}$ hamil terinfeksi HIV di regional Asia Tenggara. Negara dengan high burden penularan infeksi HIV dari ibu ke anak seperti India, Thailand, Myanmar dan Indonesia menunjukan estimasi insidens HIV diantara ibu hamil cenderung tetap selama lima tahun terakhir. Jumlah anak kurang dari 15 tahun yang terinfeksi telah HIV sebesar 87.000 dengan estimasi infeksi HIV baru sebesar 48.000. Data estimasi UNAIDS/WHO (2009) juga memperkirakan 22.000 anak di wilayah Asia Pasifik terinfeksi HIV dan tanpa pengobatan, setengah dari anak yang terinfeksi tersebut akan meninggal sebelum ulang tahun kedua. (Kemenkes, 2013).

HIV merupakan penyebab utama kematian perempuan usia reproduksi. Pada tahun 2010 diperkirakan terdapat $57.000 \mathrm{ibu}$ hamil terinfeksi HIV di regional Asia Tenggara. Negara dengan high burden penularan infeksi HIV dari ibu ke anak seperti India, Thailand, Myanmar dan Indonesia menunjukan estimasi insidens HIV diantara ibu hamil cenderung tetap selama lima 
tahun terakhir. Jumlah anak kurang dari 15 tahun yang terinfeksi telah HIV sebesar 87.000 dengan estimasi infeksi HIV baru sebesar 48.000. Data estimasi UNAIDS/WHO (2009) juga memperkirakan 22.000 anak di wilayah Asia Pasifik terinfeksi HIV dan tanpa pengobatan, setengah dari anak yang terinfeksi tersebut akan meninggal sebelum ulang tahun kedua. (Kemenkes, 2013).

Sejak tahun 2000 Indonesia memasuki klasifikasi endemi terkonsentrasi untuk infeksi HIV. Sampai saat ini penderita HIV/AIDS telah dilaporkan oleh 341 Kabupaten/Kota dari 497 Kabupaten/Kota di 33 Provinsi. Seiring dengan meningkatnya proporsi HIV pada perempuan $(28 \%)$, terjadi peningkatan jumlah kumulatif AIDS pada ibu rumah tangga dari 172 orang pada tahun 2004 menjadi 3368 o1 sampai bulan Juni 2012. Begitu 21 jumlah kumulatif anak dengan AIDS yang tertular HIV dari ibunya meningkat dari 48 orang pada tahun 2004 menjadi 912 sampai bulan Juni 2012.(Data Ditjen P2PL. 2012).

Data Kementerian Kesehatan (2012) menunjukkan dari 43.624 ibu hamil yang menjalani test HIV, sebanyak $1.329 \quad(3,01 \%)$ ibu hamil dinyatakan positif HIV. Hasil pemodelan matematika epidemi HIV tahun 2012 menunjukkan prevalensi HIV pada ibu hamil diperkirakan akan meningkat dari 0,38\% (2012) menjadi $0,49 \% \quad$ (2016) sehingga kebutuhan terhadap layanan PMTCT meningkat dari 12.189 (2012) menjadi 16.191 (2016).

Virus HIV dapat ditularkan dari ibu HIV kepada anaknya selama masa kehamilan, pada saat persalinan atau pada saat menyusui. PMTCT telah terbukti sebagai intervensi yang sangat efektif untuk meningkatkan kesehatan ibu dan anak. Di negara maju risiko penularan dari ibu ke anak dapat ditekan hingga kurang dari 2\% karena layanan PMTCT tersedia dan dilaksanakan secara optimal. Namun di negara berkembang atau negara miskin, dengan minimnya akses terhadap pelayanan, risiko penularan berkisar antara $\quad 25 \% \quad-45 \%$. Rendahnya pengetahuan dan informasi tentang penularan dari Ibu ke anak bisa dilihat dari hasil Riskesdas 2010 yang menunjukkan bahwa Persentase penduduk yang mengetahui bahwa HIV/AIDS dapat ditularkan dari ibu ke anak selama hamil, saat persalinan, dan saat menyusui adalah masing-masing 38,1 persen, 39,0\%, dan 37,4\%. (Kemenkes, 2013).

Sebagian besar infeksi HIV dapat dicegah dengan upaya pencegahan penularan dari ibu ke anak yang komprehensif dan efektif di fasilitas pelayanan kesehatan. Upaya pencegahan penularan HIV dari ibu ke anak yang komprehensif meliputi empat pilar atau komponen, yang dikenal sebagai "prong". (Kemenkes RI, 2012:14).

\section{METODE}

Penelitian berdasarkan tujuan penelitian yang digunakan adalah deskriptif. Penelitian deskriptif bertujuan untuk mendeskripsikan (memaparkan) peristiwa-peristiwa penting yang akan terjadi pada masa kini. 
Populasi dalam penelitian ini adalah semua ibu hamil di Desa Bandung Kecamatan Prambon Kabupaten Nganjuk yang berjumlah 42 responden. Sampel dalam penelitian ini adalah semua ibu hamil yang memenuhi kriteria inklusi di desa Bandung Kecamatan Prambun Kabupaten Nganjuk.
Teknik yang digunakan oleh peneliti adalah Sampling Purposive. Sampling Purposive adalah teknik penentuan sampel dengan pertimbangan tertentu. Yaitu sampling yang memenuhi kriteria inklusi di Desa Bandung Kecamatan Prambon kabupaten Nganjuk.

Tabel III.1 Definisi Operasional Gambaran Pengetahuan Ibu Hamil Tentang PMTCT di Desa Bandung Kecamatan Prambon Kabupaten Nganjuk

\begin{tabular}{|c|c|c|c|c|c|c|}
\hline $\begin{array}{l}\mathrm{N} \\
\mathrm{o}\end{array}$ & Variabel & $\begin{array}{c}\text { Definisi } \\
\text { Operasional }\end{array}$ & Indikator & $\begin{array}{l}\text { Alat } \\
\text { Ukur }\end{array}$ & Skala & Skor \\
\hline 1. & $\begin{array}{l}\text { Gambaran } \\
\text { Pengetahuan } \\
\text { ibu hamil } \\
\text { tentang } \\
\text { PMTCT }\end{array}$ & $\begin{array}{lr}\text { Segala sesuatu } \\
\text { yang diketahui } \\
\text { ibur hamil } \\
\text { tentang PMTCT } \\
\text { di } \quad \text { Desa } \\
\text { Bandung } \\
\text { Kecamatan } \\
\text { Prambon } \\
\text { Kabupaten } \\
\text { Nganjuk r }\end{array}$ & $\begin{array}{l}\text { Gambaran } \\
\text { pengetahuan ibu } \\
\text { hamil meliputi : } \\
\text { a. Pengetahuan } \\
\text { b. Tujuan } \\
\text { PMTCT } \\
\text { c. Cara } \\
\text { penularan } \\
\text { HIV } \\
\text { d. Cara } \\
\text { pencegahan } \\
\text { HIV }\end{array}$ & $\begin{array}{l}K \\
U \\
\text { E } \\
\text { S } \\
\text { I } \\
\text { O } \\
\mathrm{N} \\
\text { E } \\
\text { R }\end{array}$ & $\begin{array}{c}\mathrm{O} \\
\mathrm{R} \\
\mathrm{D} \\
\mathrm{I} \\
\mathrm{N} \\
\mathrm{A} \\
\mathrm{L}\end{array}$ & $\begin{array}{l}\text { Skor penilaian } \\
\text { jika } \\
\text { pertanyaan } \\
\text { Jawaban } \\
\text { Benar = } 1 \\
\text { Salah =0 } \\
\text { Kemudian dari } \\
\text { penilaian } \\
\text { tersebut } \\
\text { disimpulkan } \\
\text { dengan kriteria: } \\
\text { 1.Baik 76-75\% } \\
\text { 2.Cukup 56-75\% } \\
\text { 3.Kurang <56\% } \\
\text { (Wawan \& } \\
\text { Dewi, 2010:18) }\end{array}$ \\
\hline
\end{tabular}

Instrumen penelitian adalah alatalat yang akan digunakan untuk pengumpulan data. Instrumen penelitian ini dapat berupa kuisioner daftar pertanyaan), formulir observasi, formulir-formulir lain yang berkaitan dengan pencatatan data dan sebagainya. (Notoatmodjo, 2012: 87).

Pengolahan data dengan editing, coding, skoring dan tabulating. Analisa data dengan Dari hasil data kuisioner yang telah diisi, dihitung secara manual, ditabulasi dan diskor kemudian diprosentasekan dengan menggunakan rumus 

Keterangan :

$\mathrm{P}=$ Prosentase hasil

$\mathrm{x}=$ Jumlah jawaban benar

$\mathrm{y}=$ Nilai maksimal

Pada data pengetahuan diberikan skor 1 apabila jawaban benar dan diberikan skor 0 bila jawaban salah.
Pengetahuan dapat diklasifikasikan menjadi:
1) Baik
: $76 \%-100 \%$
2) Cukup
: $56 \%-75 \%$
3) Kurang
$:<56 \%$

\section{DISKUSI}

1. Gambaran Tingkat Pengetahuan Ibu Hamil tentang Pencegahan Penularan HIV dari Ibu ke Anak

Tabel IV.1 Distribusi Frekuensi Gambaran Pengetahuan Ibu Hamil tentang Pencegahan Penularan HIV dari ibu ke anak di Desa Bandung Kecamatan Prambon Kabupaten Nganjuk

\begin{tabular}{|c|l|c|c|}
\hline No & \multicolumn{1}{|c|}{ Pengetahuan } & Frekuensi & Prosentase ( \% ) \\
\hline 1 & Baik & 7 & 23 \\
\hline 2 & Cukup & 17 & 57 \\
\hline 3 & Kurang & 6 & 20 \\
\hline \multicolumn{2}{|c|}{ Jumlah } & 30 & 100 \\
\hline
\end{tabular}

2. Gambaran Pengetahuan Ibu Hamil tentang Pengertian, Tujuan, cara penularan HIV, Cara Pencegahan HIV

Tabel IV.2 Distribusi Frekuensi Gambaran Tingkat Pengetahuan Ibu Hamil Tentang PMTCT Pada Tanggal 11 Mei 2015

\begin{tabular}{|c|l|c|c|c|c|c|c|}
\hline \multirow{2}{*}{ No } & \multirow{2}{*}{ Kategori } & \multicolumn{2}{|c|}{ Baik } & \multicolumn{2}{c|}{ Cukup } & \multicolumn{2}{c|}{ Kurang } \\
\cline { 3 - 8 } & & F & \% & F & \% & F & \% \\
\hline 1 & Pengertian PMTCT & 22 & 73 & 7 & 23 & 1 & 3 \\
\hline 2 & Tujuan PMTCT & 6 & 20 & - & - & 24 & 80 \\
\hline 3 & Cara penularan HIV & 3 & 10 & 13 & 43 & 14 & 47 \\
\hline 4 & Cara Pencegahan HIV & 15 & 50 & 9 & 30 & 6 & 20 \\
\hline
\end{tabular}

1. Pengetahuan Remaja Putri Usia 17-19 tahun tentang Imunisasi HPV Sebelum Diberi Penyuluhan

Berdasarkan hasil penelitian yang dilakukan pada 113 responden untuk mengidentifikasi pengetahuan remaja putri usia 1719 tahun tentang imunisasi HPV sebelum diberi penyuluhan dapat diketahui bahwa 99 responden $(87,61 \%)$ memiliki pengetahuan yang kurang, 14 respon 24 $(12,39 \%)$ memiliki pengetahuan yang cukup, sedangkan tidak ada responden yang memiliki pengetahuan baik.

Imunisasi HPV adalah upaya pencegahan primer untuk mencegah 
kanker serviks, dengan cara meningkatkan kemampuan sistem imun untuk mengenali dan menghancurkan virus ketika masuk kedalam tubuh sebelum terjadi infeksi (Maharani,2009 : 85). Pengetahuan juga bisa disebut sebagai informasi atau maklumat yang diketahui atau disadari oleh seseorang. Dalam pengertian lain, pengetahuan adalah berbagai gejala yang ditemui dan diperoleh manusia melalui pengamatan akal (Wordpress, 2008).Penyuluhan kesehatan adalah kegiatan pendidikan kesehatan, yang dilakukan dengan cara menyebarkan pesan, menanamkan keyakinan, sehingga masyarakat tidak saja sadar, tahu dan mengerti, tetapi juga mau dan bisa melakukan suatu anjuran yang ada hubungannya dengan kesehatan (Machfoedz\& Eko Suryani, 2006).

Pada dasarnya dengan adanya imunisasi HPV, kesempatan untuk mengurangi angka kejadian kanker serviks sangat terbuka lebar terutama pada remaja. Jika sudah mendapat informasi dan ada kemauan dari remaja putri khususnya di akademi kebidanan dharma husada kediri, dimana yang latar belakang ekonominya mayoritas berada di posisi menengah keatas, seharusnya pelaksanaan imunisasi HPV bisa dilasanakan, disisi lain sebagai calon petugas kesehatan bisa mempelopori pelaksanaan imunisasi HPV terlebih dahulu sebagai contoh masyarakat luas nantinya saat terjun ke masyarakat. Namun karena faktorfaktor lain, kebanyakan masyarakat khususnya remaja putri malas untuk mencari informasi baru, selain itu mereka juga lebih mengutamakan kebutuhan sekunder dari pada memikirkan kesehatan tubuhnya terutama dalam hal kesehatan reproduksi mereka.

\section{Pengetahuan Remaja Putri Usia 17-19 tahun tentang Imunisasi HPV Sesudah Diberi Penyuluhan}

Hasil penelitian pengetahuan remaja putri usia 17-19 tahun tentang imunisasi HPV sesudah diberi penyuluhan pada 113 responden, yang memiliki pengetahuan dengan kriteria baik yaitu sebanyak 94 responden $(83,19 \%)$, yang memiliki pengetahuan dengan kriteria cukup sejumlah 19 responden (16,81\%) dan tidak ada responden yang memiliki pengetahuan dengan kriteria kurang.

Faktor yang mempengaruhi pengetahuan salah satunya adalah karakteristik responden berdasarkan usia. Berdasarkan hasil penelitian didapatkan ba' responden dengan usia 17 t: 25 tidak ada (0\%), usia 18 tahun 15 orang $(13,27 \%)$, usia 19 tahun 98 orang $(86,73 \%)$.

Usia adalah umur individu yang dihitung mulai saat dilahirkan sampai saat ulang tahun. Semakin cukup umur, tingkat kematangan dan kekuatan seseorang akan lebih terpikir matang. Seseorang yang mempunyai usia lebih tua cenderung mempunyai pengetahuan lebih banyak (Wawan\& Dewi, 2010 :17)

Adanya peningkatan pengetahuan pada penelitian ini dikarenakan adanya penyuluhan kesehatan. Penyuluhan kesehatan merupakan gabungan bebagai kegiatan dan kesempatan yang 
berlandaskan prinsip-prinsip belajar untuk mencapai suatu keadaan, diman individu, keluarga, kelompok atau masyarakat secara keseluruhan ingin hidup sehat, tahu bagaimana caranya dan melakukan apa yang bisa dilakukan, secara perseorangan maupun secara kelompok (Wordpress, 2008).

Pada usia 19 tahun merupakan usia yang reproduktif bagi seseorang untuk dapat memotifasi diri memperoleh pengetahuan yang sebanyak-banyaknya. Pada usia reproduktif tersebut seseorang akan cenderung ingin banyak memperoleh informasi karena terdorong oleh naluri pada diri untuk merubah diri dan sikap khususnya penfetahuan tentang kesehatan reproduksinya. Karena pada usia tersebut adalah usia dimana remaja putri mulai mengalami masalah-masalah kewanitaan seperti keputihan dan sebagainya, sehingga rasa ingin tahu akan lebih tinggi karena keinginannya untuk menjaga kesehatan reproduksinya mulai muncul.

\section{Perbedaan Pengetahuan}

Remaja Putri Usia 17-19 tahun tentang Imunisasi HPV Sebelum dan Sesudah Diberi Penyuluhan

Hasil uji statistik dengan menggunakan uji wilcoxon (Wilcoxon Match Pair Test) pada 113 responden, yang dihitung dengan komputer menunjukkan hasil nilai $Z$ sebesar -9,195 dengan nilai signifikansi $(\sigma)$ sebesar 0,000 . Hal ini berarti nilai signifikansi perbedaan pengetahuan remaja putri sebelum dan sesudah diberi penyuluhan dengan tingkat kesalahan $(\alpha) 5 \%$ atau 0,05 sebesar $0,000 \quad(\sigma \leq 0,05)$. Dari hasil analisis, menunjukkan bahwa pengetahuan responden sebelum diberi penyuluhan dibandingkan sesudah diberi penyuluhan terjadi peningkatan yaitu sebanyak 112 responden $(99,12 \%)$, dengan tingkat signifikansi $(\sigma)=0,000(\sigma$ $\leq 0,05)$, maka $\mathrm{H}_{1}$ diterima, yang artinya ada perbedaan antara pengetahuan remaja putri usia 1719 tahun tentang imunisasi HPV sebelum dan sesudah diberi penyuluhan.

Adanya

perbedaan pengetahuan remaja putri usia 1719 tahun tentang imunisasi HPV ditunjang oleh data khusus. Peningkatan terbanyak yaitu pada kategori baik dari tidak ada responden yang memiliki kriteria baik $(0 \%)$ menjadi 94 responden $(83,19 \%) \quad$ yang mem ${ }^{: 1: 1: \text { r }}$ pengetahuan dalam kriteria $\mathrm{t} 26$ Dari hasil tabulasi menunjukkan bahwa lebih dari 50\% responden menjawab benar pada materi meliputi pengertian imunisasi HPV, sediaan, komposisi imunisasi HPV, dan biaya imunisasi HPV.

Pengetahuan akan terus berkembang seiring dengan pertambahan usia dan tuntutan hidup seseorang. Sehingga pengetahuan yang diperoleh dari proses pendidikan yang dimulai sejak lahir, baik formal maupun non formal akan sangat menentukan seseorang dalam 
menghadapi lingkungan.

(Notoatmodjo, 2003).

Perbedaan pengetahuan remaja putri usia 17-19 tahun tentang imunisasi HPV sebelum dan sesudah dilakukan penyuluhan terlihat dari isian kuesioner dimana pada umumnya terdapat peningkatan. Sebelum dilakukan penyuluhan terdapat nilai terendah

\section{SIMPULAN}

Dari hasil penelitian pada 113 responden dengan judul "Perbedaan Pengetahuan Remaja Putri Usia 17-19 tahun tentang Imunisasi HPV Sebelum dan Sesudah Diberi Penyuluhan di Akademi Kebidanan Dharma Husada Kediri”, dapat ditarik kesimpulan sebagai berikut:

1. Pengetahuan remaja putri usia $17-$ 19 tahun tentang imunisasi HPV sebelum diberi penyuluhan menunjukkan pengetahuan dengan kriteria kurang sebanyak 99 responden $(87,61 \%)$.

2. Pengetahuan remaja putri usia 1719 tahun tentang imunisasi HPV sesudah diberi penyuluhan pada kuesioner yaitu yang merupakan vaksin kombinasi yang terdiri dari 2 spesies HPV, namun setelah dilakukan penyuluhan ada peningkatan nilai yaitu $(97,35 \%)$ dimana sebelumnya hanya bernilai $(22,12 \%)$. Dan tidak ada penurunan nilai pada soal-soal yang ada setelah diberikan penyuluhan.

menunjukkan bahwa 94 responden $(83,19 \%)$ memiliki pengetahuan dengan kriteria baik.

3. Dari hasil uji statistic, diperoleh nilai signifikansi $(\sigma)$ sebesar 0,000 , dengan tingkat kesalahan $(\alpha)=$ 0,05 yang artinya $\sigma \leq 0,05$ sehingga dalam penelitian ini $\mathrm{H}_{1}$ diterima, yang berarti ada perbedaan pengetahuan remaja putri usia 17-19 tahun tentang imunisasi HPV sebelum dan sesudah diberi penyuluhan

\section{DAFTAR PUSTAKA}

Ali\&Asrori. 2010. Psikologi Remaja Perkembangan Peserta Didik. Jakarta : PT Bumi Aksara

Arikunto,Suharsimi. 2006. Prosedur Penelitian Suatu Pendekatan Praktek Edisi Revisi VI. Jakarta : Rineka Cipta

Cahyono,Suharjo. 2010. Vaksinasi, Cara Ampuh Cegah Penyakit Infeksi. Yogyakarta : Kanisius

Hidayat,A.Aziz Alimul. 2011. Metode penelitian Kebidanan dan teknik analisis Data . Jakarta: Salemba Medika

Kusmiran,Eny. 2011. Kesehatan Reproduksi Remaja dan Wanita. Jakarta : Salemba Medika

Maharani,Sabrina. 2009. Kanker Mengenal $13 \quad$ Jenis Kanker\&Pengobatannya.

Jogjakarta : Katahati

Mubarak,Wahit Iqbal. 2011. Promosi Kesehatan Untuk Kebidanan. Jakarta : Salemba Medika 
Notoatmodjo, Soekidjo. 2005. Metodologi Penelitian Kesehatan. Jakarta : PT Rineka Cipta

Nursalam. 2003. Konsep dan Penerapan Metodologi Penelitian Ilmu Keperawatan. Jakarta:Salemba Medika 2008. Konsep dan Penerapan Metodologi Penelitian Ilmu Keperawatan. Jakarta:Salemba Medika

Nurwijaya,Andrijono\&Suheimi. 2010. Cegah dan Deteksi Kanker Servik. Jakarta : Gramedia

Poltekkes Depkes. 2010. Kesehatan Remaja Problem dan Solusinya. Jakarta : Salemba Medika

Rasjidi\&Sulistiyanto. 2007. Vaksin Human Papilloma Virus dan Eradikasi Kanker Mulut Rahim. Jakarta : CV. Sagung Seto

Setiati,Eni. 2009. Waspadai Kanker Ganas Pembunuh Wanita.Yogyakarta : C.V Andi Offset

Tilong,Adi. 2012. Bebas Dari Ancaman Kanker Serviks. Yogyakarta : Flash Book
Wawan \& Dewi. 2010. Pengetahuan, Sikap, Dan Perilaku Manusia. Yogyakarta : Nuha Medika.

Depkes RI. 2009. Remaja Sebagai Generasi Penerus. [Available From : http://Depkes RI.com. Accessed May 16 ${ }^{\text {th }}, 2013^{\mathrm{J}}$ ]

Dinkes Jatim. 2012. Pelaksanaan Imunisasi HPV. [Available From: http://www.dinkes.jatimprov.go.id . Accessed May 10 ${ }^{\text {th }}, 2013$ ]

2004. Satu dari Lima Orang Indonesia adalah Remaja. [Available From http://www.bkkbn.go.id. Accessed May $13^{\text {th }}, 2013$ ]

Nadeyarizi. 2009. Pengetahuan Tentang Kanker Serviks. [Available From: http://www.wordpress.com. Accessed May 15 ${ }^{\text {th }}$,2013]

Sukmawati. 2011. Kanker Mulut Rahim\&Pencegahan. [Available From : http://www.lontar.ui.ac.id. Accessed May $12^{\text {th }}$,2013]

Wordpress. 2008. Penyuluhan Kesehatan. [Available From http://www.wordpress.com. Accessed May 15 ${ }^{\text {th }}, 2013$ ] 